\title{
11. A longitudinal study of information systems research in Australia
}

\author{
Graham Pervan \\ School of Information Systems \\ Curtin University of Technology \\ Graeme Shanks \\ Department of Information Systems \\ University of Melbourne
}

\begin{abstract}
This chapter reports a longitudinal study that explores the state of information systems (IS) research in Australia. A series of surveys was distributed to the heads of all IS discipline groups in Australian universities in 2004, 2005 and 2006. The study highlights the current state of IS research in Australia from the 2006 survey and analyses the trends in IS research in the past few years. The study revealed a wide range of topics researched (with rapid growth in electronic commerce and knowledge management), a range of foci, a balance between positivist and interpretive research, surveys as the most frequently used research method and the fact that most research was directed at informing IS professionals. A SWOT (strengths, weaknesses, opportunities, threats) analysis identified the growing importance of industry relevance and collaboration. Research performance, measured by publication output and research grant income, is shown to be improving, but is dominated by universities from the 'Sandstone/Redbrick' and 'Unitech' sectors, and overall does not compare favourably with other disciplines.
\end{abstract}

\section{Introduction}

The first academic programs in IS appeared in Australia in the late 1960s and have grown steadily to be available in almost all Australian universities. While the teaching of IS has grown, the growth of IS research has been slower and few studies have examined its progress. Ridley et al. (1998) studied publication performance over a seven-year period, but there has been no longitudinal study of the research profile of IS in Australian universities. 
This chapter explores the Australian IS research field along lines similar to part of the study conducted by Avgerou et al. (1999) in Europe, except that it focuses only on research, and is based on an earlier study by Pervan and Cecez-Kecmanovic (2001). The study targeted the views of the heads of discipline from Australian IS groups and was conducted on behalf of the Australian Council of Professors and Heads of Information Systems (ACPHIS).

\section{Research approach}

In order to investigate the state of IS research in Australia, a series of surveys was distributed to the heads of all IS discipline groups in Australian universities in 2004, 2005 and 2006. We focused on the 'school' level (where 'school' represents a group of people focused primarily on teaching and researching IS). The group of target respondents expected to represent these schools was the head of discipline for each of the groups identified by the Information Systems Heads of Department (ISHoDs) mailing list. Based on the previous study by Avgerou et al. (1999) and aspects of paradigm and method from Neuman (2006), a number of dimensions of the schools' research activities were identified and incorporated into the original questionnaire. The survey has been refined progressively to the current instrument, although the broad focus remains consistent. The survey contained questions on:

- people - number, level and research activity of staff, number of enrolled and completing PhD students

- $\quad$ structures - school structural titles, real names and super-organisations

- foci-topics of research interest, unit of analysis, human-technology spectrum, beneficiaries of the research

- paradigm - positivist, interpretivist or critical

- methods - survey, case study, action research, laboratory experiment, and so on

- performance - publication output, research funds obtained, collaboration.

In addition, a brief SWOT analysis of Australian IS research was added to the questionnaire.

As indicated, the target group was the groups on the ISHoDs mailing list (one response required from the head of discipline of each group) and the survey was distributed and returned via e-mail.

\section{Results}

The questionnaires were distributed electronically and, after some follow-up, 24 responses were received in 2006, 24 responses were received in 2005 and 25 responses were received in 2004. This represents a response from about 60 per cent of the universities. A number of universities, however, have no IS discipline group, so the effective response rate is more than 80 per cent (of the 30 or so IS 
groups) and can therefore be claimed to be representative of the population of IS groups as a whole. There is a mix of titles (most commonly schools, but also departments and other titles), but hereafter the groupings will be referred to as schools. The discipline titles of these schools of the 24 respondents in 2006 were 50 per cent (12 respondents) IS, 25 per cent information technology (IT) and 25 per cent other titles. Furthermore, 14 of these schools were in a business/commerce faculty, seven in an IT faculty and three in a mix of others.

Academic staff levels are shown in Table 11.1 and indicate a 2006 mean of 16.3 total academic staff in IS schools, with a reduction in size evident from 2004 and 2005. This is consistent with the reduction in IS student numbers during this period. Table 11.2 shows a breakdown into staff categories and highlights the low number of senior staff (levels D and E) and research-only staff (research fellows) in each school.

Table 11.1 Academic staff levels

\begin{tabular}{l|l|l|l|l|l|l}
\hline & $\begin{array}{l}\text { Mean } \\
\mathbf{2 0 0 4}\end{array}$ & $\begin{array}{l}\text { Range } \\
\mathbf{2 0 0 4}\end{array}$ & $\begin{array}{l}\text { Mean } \\
\mathbf{2 0 0 5}\end{array}$ & $\begin{array}{l}\text { Range } \\
\mathbf{2 0 0 5}\end{array}$ & $\begin{array}{l}\text { Mean } \\
\mathbf{2 0 0 6}\end{array}$ & $\begin{array}{l}\text { Range } \\
\mathbf{2 0 0 6}\end{array}$ \\
\hline & & & & & & \\
\hline Continuing & 17.8 & $2-40$ & 17.2 & $1-41$ & 14.4 & $3-30$ \\
\hline Contract & 2.5 & $0-12$ & 2.0 & $0-7$ & 1.9 & $0-7$ \\
\hline Total academic staff & 20.3 & & 19.2 & & 16.3 & \\
\hline
\end{tabular}

The overall view is that there is a mix of names and locations for IS schools, but the majority are medium-sized groups with IS in the name and reside in a business/commerce faculty where they can maintain a close association with the areas of application of IS.

Table 11.2 Academic staff categories

\begin{tabular}{l|l|l|l|l|l|l}
\hline & $\begin{array}{l}\text { Mean } \\
\mathbf{2 0 0 4}\end{array}$ & $\begin{array}{l}\text { Range } \\
\mathbf{2 0 0 4}\end{array}$ & $\begin{array}{l}\text { Mean } \\
\mathbf{2 0 0 5}\end{array}$ & $\begin{array}{l}\text { Range } \\
\mathbf{2 0 0 5}\end{array}$ & $\begin{array}{l}\text { Mean } \\
\mathbf{2 0 0 6}\end{array}$ & $\begin{array}{l}\text { Range } \\
\mathbf{2 0 0 6}\end{array}$ \\
\hline Research fellows & 0.9 & $0-5$ & 0.7 & $0-4$ & 0.7 & $0-4$ \\
\hline Level Es (professors) & 1.3 & $0-3$ & 1.4 & $0-3$ & 1.3 & $0-3$ \\
\hline $\begin{array}{l}\text { Level Ds (associate } \\
\text { professors) }\end{array}$ & 2.0 & $0-11$ & 1.7 & $0-4$ & 1.6 & $0-5$ \\
\hline Level Cs (senior lecturers) & 4.8 & $0-13$ & 5.3 & $0-14$ & 4.0 & $0-11$ \\
\hline Level Bs (lecturer Bs) & 8.7 & $0-23$ & 7.9 & $1-22$ & 7.3 & $1-18$ \\
\hline Level As (lecturer As) & 2.8 & $0-11$ & 2.1 & $0-10$ & 1.6 & $0-8$ \\
\hline Total & 20.5 & & 19.1 & & 16.5 & \\
\hline
\end{tabular}

Staff research activity levels are shown in Table 11.3 and indicate that in 2006 the majority (mean 83.7 per cent) of staff were doing some research although only about half of these were research active according to the strict Department of Education, Science and Training (DEST) definition (mean 41 per cent). Just more than half (mean 57.5 per cent) have PhDs and a further quarter are doing PhDs (mean 23.6 per cent). Just more than one-third (mean 37.6 per cent) are supervising PhDs and one-quarter (mean 25 per cent) have supervised a PhD to completion. It can be seen that although the proportions of staff doing some 
research and those considered DEST research-active have remained about the same, there has been an increase in the number of staff with PhDs and in supervision in the period 2004-06.

Table 11.3 Staff research activity

\begin{tabular}{l|l|l|l|l|l|l|l|l|l}
\hline & $\begin{array}{l}\text { Mean } \\
\mathbf{2 0 0 4}\end{array}$ & $\begin{array}{l}\text { Range } \\
\mathbf{2 0 0 4}\end{array}$ & $\begin{array}{l}\text { \% } \\
\mathbf{2 0 0 4}\end{array}$ & $\begin{array}{l}\text { Mean } \\
\mathbf{2 0 0 5}\end{array}$ & $\begin{array}{l}\text { Range } \\
\mathbf{2 0 0 5}\end{array}$ & $\begin{array}{l}\text { \% } \\
\mathbf{2 0 0 5}\end{array}$ & $\begin{array}{l}\text { Mean } \\
\mathbf{2 0 0 6}\end{array}$ & $\begin{array}{l}\text { Range } \\
\mathbf{2 0 0 6}\end{array}$ & $\begin{array}{l}\text { \% } \\
\mathbf{2 0 0 6}\end{array}$ \\
\hline Doing some research & - & - & - & 15.3 & $1-37$ & 80.1 & 13.4 & $4-30$ & 83.7 \\
\hline Research active (DEST) & 7.9 & $0-21$ & 43.9 & 6.3 & $0-18$ & 37.5 & 6.0 & $0-18$ & 41.9 \\
\hline Doing PhDs & - & - & - & 5.2 & $1-16$ & 28.7 & 3.8 & $0-11$ & 23.6 \\
\hline Have PhDs & 8.7 & $2-24$ & 43.5 & 9.3 & $1-24$ & 51.3 & 8.6 & $3-22$ & 57.5 \\
\hline Supervising PhDs & 6.1 & $1-15$ & 31.6 & 6.2 & $1-16$ & 36.0 & 5.7 & $1-16$ & 37.6 \\
\hline $\begin{array}{l}\text { Supervised } \geq 1 \mathrm{PhD} \text { to } \\
\text { completion }\end{array}$ & 3.1 & $0-8$ & 17.0 & 3.3 & $0-8$ & 19.8 & 3.5 & $0-9$ & 25.0 \\
\hline
\end{tabular}

Doctoral student numbers are shown in Table 11.4 and it can be seen that the mean number of doctoral students and the mean number of $\mathrm{PhD}$ completions per school have remained much the same since 2004. The results indicate that in 2006 the mean number of full-time equivalent (FTE) PhD students in each school was 11.5 (7.8 full-time and half of 7.4 part-time), while the mean number of $\mathrm{PhD}$ graduations per school in the previous year was 1.4. With that many PhD students, there would be an expectation of three to four graduates per annum (based on a target of 3.5 FTE years for completion of a PhD), but the real completion rate is less than half that. This signals a throughput problem, which might exist because of variable-quality supervision practices (within schools and across the sector) and a lack of adequate resources, which needs to be addressed.

\section{Table 11.4 Doctoral student numbers}

\begin{tabular}{l|c|c}
\hline & Mean & Range \\
\hline Enrolled full-time 2004 & 8.0 & $0-25$ \\
\hline Enrolled part-time 2004 & 7.9 & $0-23$ \\
\hline Enrolled full-time 2005 & 8.2 & $0-21$ \\
\hline Enrolled part-time 2005 & 8.4 & $0-23$ \\
\hline Enrolled full-time 2006 & 7.8 & $0-26$ \\
\hline Enrolled part-time 2006 & 7.4 & $0-25$ \\
\hline 2002 graduates & 0.6 & $0-2$ \\
\hline 2003 graduates & 1.3 & $0-6$ \\
\hline 2004 graduates & 1.6 & $0-5$ \\
\hline 2005 graduates & 1.4 & $0-3$ \\
\hline
\end{tabular}

Respondents were asked to indicate the topics of research interest in the past, present and future, and responses for the 2006 survey are summarised in Table 11.5 below, sorted by future topic of interest. The results demonstrate the substantial interest in research on IS management and strategy and the organisational implications of IS and IT, IS adoption/diffusion, electronic commerce and knowledge management, with almost all groups indicating an 
interest in these areas. In addition, interest is strong in topics such as IS development and business modelling, mobile commerce and the theoretical underpinnings of IS. On the other hand, specific topics and technical issues such as computer and network applications and computer-supported cooperative work (CSCW)/groupware are relatively less popular. It should be pointed out, however, that the table reveals how many groups are interested in these topics and does not show how large these groups are. So, further research is needed at the individual researcher level.

The respondents were asked also to indicate the usual unit of analysis of their research. In the 2006 survey this was the organisation (22 responses), groups/teams (19), clusters of organisations (19), industry (16), processes/tasks (15), individuals (14), national economy/society (eight) and world economy/society (three). Clearly, researchers focused most on organisations and the people within them, and significantly less on studying IS at the national or global levels. This could represent an opportunity to collaborate with other researchers (for example, economists) to investigate the impact of IS and information technologies on Australia's economy and its links with the region and globally. In terms of a research paradigm, responses revealed dominance of the positivist paradigm (in 71 per cent of schools), but the interpretivist paradigm was also used often (54 per cent). The survey data confirmed a growing recognition that IS researchers in Australia did conduct research based on non-positivist research paradigms. Few mentioned any significant emphasis on research using a critical paradigm, which was also the case at the international level (Mingers 2001).

Table 11.5 IS research topics (2006 survey data)

\begin{tabular}{l|l|l|l|l|l|l|l}
\hline Topic & Past & Present & Future & Topic & Past & Present & Future \\
\hline $\begin{array}{l}\text { Organisational implications } \\
\text { of IS\&T }\end{array}$ & 19 & 21 & 20 & $\begin{array}{l}\text { Human-computer } \\
\text { interaction }\end{array}$ & 11 & 11 & 10 \\
\hline IS management/strategy & 17 & 17 & 16 & Systems development & 13 & 10 & 9 \\
\hline Electronic commerce & 19 & 18 & 16 & $\begin{array}{l}\text { Knowledge-based/expert } \\
\text { systems }\end{array}$ & 11 & 12 & 9 \\
\hline IS adoption/diffusion & 16 & 16 & 15 & Economic effects of IS\&T & 5 & 8 & 8 \\
\hline Knowledge management & 13 & 17 & 14 & Databases & 9 & 9 & 8 \\
\hline $\begin{array}{l}\text { Theoretical underpinnings } \\
\text { of IS }\end{array}$ & 15 & 14 & 13 & DSS/EIS/data warehousing & 9 & 9 & 7 \\
\hline IS development methods & 12 & 12 & 13 & IS outsourcing/offshoring & 5 & 7 & 7 \\
\hline Mobile commerce & 7 & 13 & 13 & $\begin{array}{l}\text { Legal/ethical aspects of } \\
\text { IS\&T }\end{array}$ & 8 & 8 & 7 \\
\hline Business modelling & 10 & 13 & 13 & $\begin{array}{l}\text { Computer and network } \\
\text { applications }\end{array}$ & 3 & 3 & 3 \\
\hline Societal effects of IS\&T & 10 & 12 & 11 & CSCW/groupware & 6 & 3 & 3 \\
\hline IS security & 8 & 9 & 10 & & & & \\
\hline
\end{tabular}

When asked to indicate the specific research methods used, the responses revealed that the full range of research methods were being applied by IS researchers (see Table 11.6 below, sorted by the research method used most 
often). The most popular method is the survey, but also popular are positivist and interpretive case studies, and design science. This balanced application of paradigm and method is perhaps an indicator that Australian IS researchers are more like their European than their North American counterparts. Arnott and Pervan (2005) found that, in published research in decision support systems, North American journals were overwhelmingly positivist whereas European journals were more balanced on paradigm and method. Again, these data are at a school level, so a study of individual researchers is needed to reveal the true extent of usage of the different methods.

Table 11.6 Research methods used (2006 survey data)

\begin{tabular}{|c|c|c|c|c|}
\hline & Never & Sometimes & Often & Always \\
\hline Survey & 0 & 7 & 16 & 1 \\
\hline Interpretivist case study & 2 & 7 & 15 & 0 \\
\hline Positivist case study & 3 & 10 & 11 & 0 \\
\hline Design science & 0 & 13 & 10 & 1 \\
\hline Literature meta-analysis & 5 & 13 & 2 & 4 \\
\hline $\begin{array}{l}\text { Business } \\
\text { modelling/simulation }\end{array}$ & 7 & 11 & 4 & 2 \\
\hline Secondary data analysis & 5 & 13 & 5 & 1 \\
\hline IS development & 6 & 12 & 6 & 0 \\
\hline Action research & 6 & 13 & 5 & 0 \\
\hline Conceptual study & 4 & 16 & 3 & 1 \\
\hline Ethnography & 10 & 11 & 3 & 0 \\
\hline Longitudinal case study & 5 & 17 & 2 & 0 \\
\hline Laboratory experiment & 11 & 11 & 2 & 0 \\
\hline
\end{tabular}

Respondents in the 2006 survey indicated clearly that the primary beneficiaries of their research were other IS academics (20), managers (17) and IS professionals (15 responses), followed distantly by end users/workers (seven), policymakers (six) and people in general (zero). This might again show that we (IS researchers) are not taking up the opportunity to influence governments and society, and it could be a major reason for the apparent lack of recognition of IS as a discipline by some government agencies. Respondents indicated that, where it occurred, most research collaboration occurred with IS colleagues within that particular academic group. Clearly, there is a need to widen the collaboration net nationally and internationally, which could help to increase quality, and with practitioners, which increases relevance and provides opportunities for funding - for example, the Australian Research Council (ARC) Linkage grants. It could also serve to enhance the impact of IS research, which might be an advantage in the research quality-assurance mechanism that will replace the proposed Research Quality Framework (RQF), once developed. The planned RQF was abandoned in December 2007 by the new Labor government.

School research output is shown in Table 11.7 and indicates that in 2006 schools generated a mean of about 52 publications, 34 of which were conference papers, 11 journal papers and a small number of other types. It can be seen that there 
has been a substantial increase in the mean number of publications in the period 2002-05. The largest increase has been in conference papers, although the number of journal papers has also increased.

Table 11.7 Publications per school

\begin{tabular}{l|l|l|l|l}
\hline & $\begin{array}{l}\mathbf{2 0 0 2} \\
\text { mean }\end{array}$ & $\begin{array}{l}\mathbf{2 0 0 3} \\
\text { mean }\end{array}$ & $\begin{array}{l}\mathbf{2 0 0 4} \\
\text { mean }\end{array}$ & $\begin{array}{l}\mathbf{2 0 0 5} \\
\text { mean }\end{array}$ \\
\hline Refereed journal papers & 6.3 & 10.0 & 9.8 & 11.0 \\
\hline $\begin{array}{l}\text { Refereed conference } \\
\text { papers }\end{array}$ & 21.1 & 29.2 & 29.1 & 33.8 \\
\hline Chapters in books & 4.3 & 3.7 & 3.4 & 5.3 \\
\hline Authored books & 0.4 & 0.9 & 0.4 & 0.6 \\
\hline Edited books/proceedings & 0.6 & 0.8 & 0.5 & 1.7 \\
\hline Total publications & 32.7 & 44.6 & 43.2 & 52.4 \\
\hline
\end{tabular}

Research performance per staff member is shown in Table 11.8 and indicates that in 2005 the mean output per academic staff member was 2.6 publications per annum and the mean grant income per academic staff member was about $\$ 17800$ per annum. It can be seen that there has been a substantial increase in publications and grant income since 2002, although the rate of increase has decreased substantially and the differences between 2004 means and 2005 means are very small. Further, Tables 11.7 and 11.8 reveal that the mean number of journal papers (of any type - there was no assessment of journal quality) per IS academic is much less than one per annum. Follow-up investigation would be required to determine publication rates in tier-one and tier-two journals, but it is certain to be even lower. This would have severely limited the chances of IS research groups achieving a high rating in the proposed RQF process - thus constraining IS research funding.

\section{Table 11.8 Research performance (per staff member)}

\begin{tabular}{l|l|l|l}
\hline & Mean & Median & Range \\
\hline 2002 publications & 1.6 & 1.3 & $0.0-4.4$ \\
\hline 2003 publications & 2.3 & 2.1 & $0.0-6.7$ \\
\hline 2004 publications & 2.3 & 2.4 & $0.4-3.9$ \\
\hline 2005 publications & 2.6 & 2.2 & $0.3-8.5$ \\
\hline 2002 grant \$K & 8.9 & 2.8 & $0.0-45.6$ \\
\hline 2003 grant \$K & 15.5 & 9.7 & $0.0-48.9$ \\
\hline 2004 grant \$K & 17.0 & 14.8 & $0.0-63.6$ \\
\hline 2005 grant \$K & 17.8 & 15.0 & $0.0-53.3$ \\
\hline
\end{tabular}

Research grant income per school is shown in Table 11.9 and indicates that in 2005 the mean grant income was more than $\$ 300000$ per annum. The amount of research grant income varied considerably between the groups, with a few groups doing very well in gaining funds from external sources, but most having to depend on internal university resources. The main source of research grant income in 2006 was from the ARC (Linkage and Discovery grants), although substantial research income was also generated from collaborative research centres (CRCs), industry contracts and internal university resources. It can be 
seen that although the total research income increased significantly after 2002, it has remained much the same throughout 2003-05. Generally, these figures compare poorly with other disciplines, including computer science and computer engineering.

Table 11.9 Research grant income (\$K) (per school)

\begin{tabular}{l|l|l|l|l|l|l|l|l}
\hline & $\begin{array}{l}\mathbf{2 0 0 2} \\
\text { mean }\end{array}$ & $\begin{array}{l}\mathbf{2 0 0 2} \\
\text { median }\end{array}$ & $\begin{array}{l}\mathbf{2 0 0 3} \\
\text { mean }\end{array}$ & $\begin{array}{l}\mathbf{2 0 0 3} \\
\text { median }\end{array}$ & $\begin{array}{l}\mathbf{2 0 0 4} \\
\text { mean }\end{array}$ & $\begin{array}{l}\mathbf{2 0 0 4} \\
\text { median }\end{array}$ & $\begin{array}{l}\mathbf{2 0 0 5} \\
\text { mean }\end{array}$ & $\begin{array}{l}\mathbf{2 0 0 5} \\
\text { median }\end{array}$ \\
\hline ARC Linkage & 68.9 & 0.0 & 107.8 & 0.0 & 90.2 & 6.0 & 98.8 & 20.0 \\
\hline ARC Discovery & 32.4 & 0.0 & 58.4 & 0.0 & 64.8 & 0.0 & 33.7 & 0.0 \\
\hline Internal university & 32.5 & 20.0 & 58.5 & 45.0 & 47.6 & 15.6 & 58.6 & 20.0 \\
\hline CRC & - & - & - & - & 46.5 & 0.0 & 60.0 & 0.0 \\
\hline Industry contract & 10.5 & 0.0 & 32.8 & 0.0 & 46.3 & 0.0 & 41.2 & 0.0 \\
\hline Consulting & 4.4 & 0.0 & 12.3 & 0.0 & 9.6 & 0.0 & 11.4 & 0.0 \\
\hline International & 8.0 & 0.0 & 3.1 & 0.0 & 4.8 & 0.0 & 1.1 & 0.0 \\
\hline Other (various) & 22.8 & 0.0 & 28.8 & 0.0 & 3.3 & 0.0 & 0.0 & 0.0 \\
\hline $\begin{array}{l}\text { National Health and } \\
\text { Medical Research Council } \\
\text { (NHMRC) }\end{array}$ & - & - & - & - & 0.0 & 0.0 & 2.0 & 0.0 \\
\hline Total & 179.5 & & & & & & & \\
\hline
\end{tabular}

Table 11.10 shows a comparison of several research variables with significantly different means across university categories. The university categories are based on those of Marginson and Considine (2000) and provide a useful means of comparing research performance. The categories are defined as follows (Marginson and Considine 2000:15-16):

- Sandstone/Redbricks: established before World War I (Sandstones) or in the 1940s-1950s (Redbricks)

- Unitechs: the former institutes of technology

- Gumtrees: founded between the early 1960s and mid-1970s

- New: founded after 1986.

It is clear from Table 11.10 that the mean size of IS schools in each of the categories is very similar. The Sandstone/Redbrick and Unitech categories have, however, significantly greater mean numbers of professors, mean numbers of DEST research-active staff, mean numbers of doctoral students, mean numbers of papers in refereed journals and refereed conferences, mean numbers of publications per staff member, mean total amounts of grant income and mean grant incomes per staff member. This is consistent with the research-intensive nature of universities in the Sandstone/Redbrick category and the historical location of IS schools within the Unitech universities. 
Table 11.102006 significant means across university categories

\begin{tabular}{l|c|c|c|c}
\hline & $\begin{array}{c}\text { Sandstone/ } \\
\text { Redbricks }\end{array}$ & Unitechs & Gumtrees & New \\
\hline Total academic staff & 15.5 & 17.0 & 17.8 & 16.1 \\
\hline Number of professors & 1.4 & 2.3 & 0.3 & 0.9 \\
\hline Number of DEST research active & 8.5 & 6.3 & 3.3 & 4.2 \\
\hline Number of doctoral students (EFT) & 16.0 & 12.7 & 6.7 & 7.4 \\
\hline \multicolumn{1}{c|}{ Papers in refereed journals } & 14.0 & 13.2 & 7.3 & 7.8 \\
\hline Papers in refereed conferences & 39.5 & 51.2 & 17.3 & 21.2 \\
\hline Publications per staff member & 3.0 & 3.5 & 1.2 & 2.0 \\
\hline Total grants (\$,000) & 397.1 & 500.8 & 26.0 & 179.1 \\
\hline Grant \$ per staff member (\$,000) & 23.6 & 29.1 & 0.9 & 10.0 \\
\hline
\end{tabular}

The final part of the survey allowed each respondent to suggest the three main strengths, weaknesses, opportunities and threats (SWOT) for the IS discipline research; a summary of the most frequently cited issues in the 2006 survey is provided in Table 11.11. In total, more than 150 ideas were generated in the SWOT and the top five in each category are presented here.

\section{Table 11.11 Results from the SWOT analysis}

\begin{tabular}{l|l}
\hline Strengths & Weaknesses \\
\hline Industry relevance and links (10) & Lack of industry relevance (8) \\
\hline Diversity of method (6) & Lack of identity of IS as a discipline (6) \\
\hline Diversity of research undertaken (5) & Poor funding and recognition by funding bodies (6) \\
\hline Feeling of community (ACIS, ACPHIS) (4) & Poor/variable research training (5) \\
\hline Critical mass of quality IS researchers (3) & Conflicts of research focus (5) \\
\hline Opportunities & Threats \\
\hline Industry collaboration/linkage grants (13) & Falling student numbers/staffing (9) \\
\hline Raising profile in industry and government (6) & Other fields claiming IS as their own (8) \\
\hline Cooperative doctoral research training (4) & Lack of research funding (6) \\
\hline Collaboration generally (3) & $\begin{array}{l}\text { Nelson Higher Education Policy/Research Quality } \\
\text { Framework (6) }\end{array}$ \\
\hline Improved quality and success (2) & Lack of industry relevance/recognition (4) \\
\hline
\end{tabular}

The respondents clearly believe there is strength in our diversity and relevance. Diversity was indicated in types of research undertaken, the research approaches taken (and the underlying epistemology) and in the breadth of experience most IS researchers brought with them from their background in IS practice and their grounding in practitioner activity. These strengths in diversity and relevance need to be nurtured and exploited.

Key weaknesses are the lack of relevance and identity and poor funding (relative to computer science/computer engineering), which is associated with other weaknesses such as the lack of a research culture in Australian business and lack of recognition from funding agencies such as the ARC. These and other research focus and training issues need to be overcome.

The respondents clearly recognise that there are numerous opportunities of which we should attempt to take advantage. In this, collaboration (with industry, 
international colleagues and other Australian universities) is the key. In addition and as indicated earlier, the opportunity exists for IS to increase its profile and recognition by conducting research on societal and economic issues, which might influence government policy.

While industry collaboration was seen as an opportunity, it could also be a threat if proper linkages were not built. Research impact will be critical in any research quality-assurance mechanism. Perhaps the greatest threats to IS research in Australian universities lie in the lack of recognition of IS as a discipline and its location in the academic structure, the falling numbers and excessive teaching loads in most schools and the career and financial opportunities outside academia.

\section{Conclusions and future work}

In this chapter, we have presented a longitudinal analysis of an annual survey of Australian IS 'heads of discipline', which shows something of the current state of IS research in Australia from the 2006 survey and analyses the trends in IS research in the past few years. The study has revealed that, in terms of research, IS schools in Australian universities seek and demonstrate diversity in topic, paradigm and method. Publication and research grant performance is steadily improving, particularly in Sandstone/Redbrick and Unitech universities, but it varies significantly across the sector and within schools and even the better performers do not compare particularly well with other, more established, academic disciplines.

It should be noted that the data collected and presented do not necessarily represent the views of individual IS researchers. Future work is needed to obtain those views. The chapter can, however, and should be used to initiate discussion within the IS academic community on where we are, where we want to be in the future and how we aim to get there.

\section{References}

Arnott, D. and Pervan, G. 2005, 'A critical analysis of decision support systems research', Journal of Information Technology, vol. 20, no. 2, pp. 67-87.

Avgerou, C., Siemer, J. and Bjørn-Andersen, N. 1999, 'The academic field of information systems in Europe', European Journal of Information Systems, vol. 8, pp. 136-53.

Marginson, S. and Considine, M. 2000, The Enterprise University: Power, Governance and Reinvention in Australia, Cambridge University Press, Cambridge, UK.

Mingers, J. 2001, 'Combining IS research methods: towards a pluralist methodology', Information Systems Research, vol. 12, no. 3, pp. 240-59. 
Neuman, W. L. 2006, Social Research Methods: Qualitative and Quantitative Approaches, 6th edn, Allyn and Bacon, Needham Heights, Massachusetts, USA.

Pervan, G. P. and Cecez-Kecmanovic, D. 2001, 'The status of information systems research in Australia: stage 1-the HODs view', Proceedings of the 12th Australasian Conference on Information Systems, Coffs Harbour, NSW, Australia, 5-7 December, pp. 503-6.

Ridley, G., Goulding, P., Lowry, G. and Pervan, G. P. 1998, ‘The Australian information systems research community: an analysis of mainstream publication outlets', Australian Journal of Information Systems, vol. 5, no. 2, pp. 69-80. 